\title{
Using Financial Ratios to Predict Financial Distress of Jordanian Industrial Firms "Empirical Study Using Logistic Regression"
}

\author{
Kerroucha Fatima Zohra1 \\ Dr. Bensaid Mohamed ${ }^{2}$ \\ Dr.Turki Elhamoud ${ }^{3}$ \\ Dr. Mohamed Garaibeh 4 \\ Attaoui Ilhem 5 \\ Halim Naimi 6 \\ 1,2,5 Djillali Liabes University - Sidi Bel Abbes- Algeria \\ ${ }^{6}$ center University Ain temouchent- Ain Temouchent -Algeria \\ 3,4Yarmouk University-Jordan \\ kerrouchafatima@hotmail.fr
}

\section{Doi:10.5901/ajis.2015.v4n2p137}

\section{Abstract}

This study aims to find consisting model of a set of financial ratios in which each ratio has its own weight that indicate its importance in discriminating between industrial distressed and non distressed firms in Jordan. The early prediction of industrial firm's distresses warned the concerned parties that they can intervene and take corrective actions before the collapses of firm. To achieve this, twenty seven ratios were calculated for a sample of twenty eight industrial firms, half of which had failed, from its financial statement for the fourth year following three years of losses for the purpose of analysis. These ratios were analyzed using the statistical method known as the logistic regression to reach the best form of financial ratios that can distinguish between industrial distressed and non distressed firms in the first, second and third year before distress. The developed model contained three financial ratios which are net working capital to owner's equity, account receivable turnover ratio, and owner's equity to fixed assets ratio, enabling the re-classification of industrial firms in the sample within the two groups of distressed and non distressed categories with accuracy amounted $89.3 \%$ in the year of analysis, whereas its accuracy in discriminating between the failed and the non failed firms was $67.9 \%, 78.6 \%, 74.1 \%$ in the first, second, and third years respectively before distress. Moreover, the model's accuracy in classifying another sample of ten firms, half of which had failed, was $90 \%$ in the first year before distress. The study concluded with some useful recommendations. The most important of them is the utilization of the proposed model by the companies control department, Ministry of industry \& Trade, current and prospective investors and company management in order to predict financial failure of industrial companies in Jordan. In addition, recommended the inclusion of non financial indicators such as firm size, its age, the various economic variables,...etc, as well as financial indicators such as financial ratios when building mathematical models to predict financial failure.

Keywords: Prediction, Distress, Financial ratios, Industrial firms, Logistic analysis.

\section{Introduction}

Predicting the financial failure of companies is one of the main topics that many international institutions have dealt with, due to its negative impact on companies, investors and the economy as a whole. The importance of financial forecasting also lies in helping decisions makers to take the appropriate decisions as far as financing is concerned. In addition to this, this latter helps reduce the degree of uncertainty as it provides an evaluation of the potential risk that may happen in the future.

As the progress of any society relies to a large extent on the success of its companies, it becomes critical to predict the financial failure of these companies to reduce or avoid the bad impact and consequences it's may have.

Thus, the purpose of financial analysis is to provide the appropriate data about the financial situation of a company as well as to evaluate its performance in a given period of time. It also helps to provide information about the extent to 
which any company has succeeded or failed to achieve its goals. Besides, this analysis permits the identifications of the indicators that show whether the company policy is appropriate or needs to be modified, helping thus in making the correct decisions within the institutions.

Due to the growing importance of financial statements, the need of financial indicators has evolved for many reasons among which one may cite: * making the appropriate decisions;" evaluating the financial situation of the company as well as its performance in a given period of time; ${ }^{*}$ forecasting the financial failure and provide some security to the people who deal with these companies.

Predicting company`s failure is also useful in the sense that it allows the administrations to take the appropriate decisions in the appropriate time to recover and get better.

Consequently, this study was considered in the definition of distress that industrial companies are those companies that made losses for three consecutive years.

The rest of the paper is organized as follows: In section two we present a literature review on the relationship. Section three evoques the model and the methodology, followed by the results and discussion in Section four, and finally, section five presents the main conclusion of this research.

\section{Problem of the Study}

The problem of the study Highlights of the need of many parties of investors, lenders and auditors, and others, to see the company's ability to survive and continuity away from failing due to the negative impact of distress companies on the national economy and the consequent of many problems as happened to find Petra Bank and the Bank of Jordan and the Gulf in the end of 1992 and many industrial companies. Since there is no indication to the use of industrial companies in Jordan and those interested in a model consists of a set of financial ratios to predict the distress of these companies before it happens, it means perhaps that the latter still rely on traditional methods of financial analysis as the reliance on these traditional methods which is based on the analysis of financial ratios of each individual, may reflect the picture is not clear-cut of the financial situation of the company and thus lead to the decisions of administrative and financial unclear, so any financial ratio can it reflect the picture of the financial situation of the company is different from what reflected other financial ratio for the same company, and given the multiplicity of uses financial ratios, it is useful to know any of these ratios which, if used together can give an accurate prediction from the failures of industrial companies before it occurs period of time to help the latter to take appropriate action and possible solutions before it is too late.

Accordingly, this study raises many questions which they can inference about the importance of the problem of the study:

1. You could develop a mathematical model is able to distinguish between distressed companies and nondistressed companies, using logistic analysis?

2. Will the proposed model, which will be reached accurately, distinguish between distressed companies and non-distressed companies before one to three years of faltering?

3. Will the proposed model, which will be reached accurately distinguish between distressed companies and nondistressed in the test sample, in the first year before faltering?

\section{The Objective of the Study}

This study aims to develop a mathematical model using the logistic analysis, consisting of a set of financial ratios, where each percentage of them weighing weighted, which reflects the degree of importance in predicting the distinction between industrial companies distressed and non-distressed, before tripping one year at least, to be used in predicting distress of Jordanian industrial companies. The objectives of the study can be summarized in the following points:

1. The main objective of this study is to try to develop a model consisting of a set of financial ratios using logistic regression to distinguish between industrial companies distressed and non-distressed companies.

2. Test the model's ability to distinguish between industrial companies distressed and non-distressed companies before tripping one year to three years, to allow for an adequate opportunity to manage the company and government agencies to take the necessary measures to reduce or prevent losses.

3. Test the model's ability to predict and apply it to another sample of industrial companies, which did not make it in the construction of the proposed model, in the first year before distress. 


\section{The Importance of the Study}

This study is gaining importance first of the importance of the industrial sector and its role in the national economy to be considered an indicator of economic development indicators.

Second of interest applied to the model quantitative study aims to develop when analyzing the published financial statements of the companies, and the possibility of universal use of this model in the Jordanian industrial sector, which will add a new financial indicator can be relied upon by investment decision makers.

The study highlights the importance of practice in that predict the distress before hindsight gives an early warning about the risk of default, hence predict corporate distress before a period stumbling of many benefits for many stakeholders, the results of these companies.

The prediction of distress enables investors to identify the fate of their investments and the disposal of investments in companies that are going in the way of failure and directing their investments to companies that are not expected to failure, and also can creditors reassurance on loans granted to companies and make decisions granting new credit. As for management, it can eliminate the causes of distress before they escalate and take the necessary corrective decisions, and for auditors, they can identify the company's ability to continuity and, finally, even the government can exercise its regulatory function to the fullest, allowing them to intervene in a timely manner.

\section{The Literature Reviews}

Many of the studies in most countries, the global developed and undeveloped countries dealt the subject of financial distress and ways to predict it, where many of those studies tried devise models appropriate to find models suitable for predicting bankruptcy or failure of companies in most sectors in the countries of the world, and will be reviewed in chronological order her:

Studies create models to predict the failure of companies has begun in the late sixties of the last century. One of the first studies in this field was the Beaver study (1966), which used the analysis of single variables and compare 14 financial ratios of companies failed to a group of successful companies and concluded that the financial ratios of the companies failed different financial ratios for companies successful, and that the ratio of cash flow to debt was the most important ratio to distinguish between these companies .Instead of them, Altman(1968) has used 22 financial ratios in building a financial analysis model discriminatory multi variables(stepwise multivariate discriminant analysis). He has reached a model that can predict the failure of companies in the year prior to the occurrence, using several financial ratios together with accurately arrived to $95 \%$. And then appeared a lot of studies that have followed the approach Altman, and used a set of financial ratios to build statistical models using discriminatory analysis and logit analysis and methods of statistical again, they reached to support the hypothesis of the possibility of the use of financial ratios in building models can predict the distress of companies with high accuracy.

\subsection{Example of these studies (Islambouli, 2003):}

The researcher study on the possibility of using financial ratios to predict the distress of industrial companies General food in Syria, and try to develop a model that could benefit from it for predicting distress of these companies, so it is an important indicator to judge the performance of such industrial companies, was by analyzing 10 financial ratios derived from the financial statements a sample of 22 companies for tracking food industrial public sector in Syria, 12 of them failed and 10 is non-failed in the period (1999-2000) using discriminatory analysis .

The researcher found a form consists of 3 ratios can be used to predict the failure of companies, namely: the rate of external funding, liquidity ratios rapid, profitable sales.

About the accuracy form in predicting distress of the companies is $100 \%$ in the study, $87.5 \%$ in the first year before faltering, $82.5 \%$ the second year before faltering, $79.17 \%$ the third year, $66.67 \%$ of the fourth year before faltering.

\subsection{Study (Rugby, 2006):}

This study aims to use financial ratios and analysis methods discriminatory and logistical support to the establishment of statistical models to predict the failure of public shareholding companies listed on the Amman Financial Market, the study included 26 companies failed and 26 successful company, was obtained from the evidence public shareholding companies during the period (1991-2002). 25 ratio was used were classified into financial liquidity and profitability ratios, 
leverage and activity.

The researcher found that the discriminatory form and logistical they can predict the failure of companies with an accuracy of $96.2 \%$ a year earlier failure, the ability of these models to predict has decreased the beginning of the second year to the fifth year prior to failure.

\section{The Hypothesis}

Based on the problem of the study and an investigation of its goal has been developed following hypotheses to be tested in this study:

1) The logistic model that consists of a set of financial ratios, which will be reached by using the regression method does not distinguish accurately between distressed companies and non-distressed companies in the analysis year.

2) The model that will be reached by using the logistic analysis does not accurately distinguish between distressed companies and non-distressed companies.

Where the second hypothesis was divided into three sub-hypotheses, namely:

- The model that will be reached using logistic analysis does not accurately distinguish between distressed companies and non-performing companies in the first year before faltering.

- The model that will be reached using logistic analysis does not accurately distinguish between distressed companies and non-performing companies in the second year before faltering.

- The model will be reached using logistic analysis does not accurately distinguish between distressed companies and non-performing companies in the third year before faltering.

3) The logistic model does not distinguish accurately between distressed companies and non-distressed companies in the test sample.

\section{The Methodology}

\subsection{The population and the sample of study:}

The study population consists of all industrial companies listed on the Amman Financial Market during the period (19952005), of which there are 94 companies, but 39 companies were excluded due to the lack of sufficient financial statements for these companies, being the exercise began its work after the year 2000 , and therefore not have the financial statements during the study period.

The study sample consists of a group of distressed companies, and a non-distressed companies is equal to the first group in the number of comparison between the two groups. It has been selected all failed companies, which has made losses for three consecutive years during the period (1995-2005). The total number of those companies 14 companies and then the other sample was selected from 14 industrial companies non-distressed.

The Annex (1) shows the sample analysis companies and the size of its assets and its financial situation during the years of the study.

The most of the previous studies Has followed style selection of a company is unsuccessful for every company failed so they are identical in type of industry and the size of the assets and the same period, but because of the lack of more than one industrial company in many industrial sectors, and provides that there may be a significant difference in the size of the assets, so the sample was selected companies is struggling to reconcile a standard type of industry and the size of the assets as much as possible. In the absence of a successful company similar to the troubled company in the industry type and size of assets have been resorting to another nearby industrial sector of the industry. In case there is a big difference between the two companies in asset size, has been resorting to another industrial sector so that the company be successful as close as possible to the company defaulted on its size.

The researcher on the way in the previously mentioned when choosing a sample of the study, although the method adopted does not require that there is a similarity between distressed companies and non-distressed companies in terms of the type of sector and asset size, but the researcher prefers so as to obtain the results of accurate and objective.

For the purposes of the test model tripping, which will be reached, was selected sample test consists of all the other failed companies during the period (2005-2009). It has been shown that there are 5 companies made losses for three consecutive years, then was chosen other 5 companies similar to the five failed companies have to be included in the test sample (Annex No. 2). 


\subsection{Statistical analysis used in the study:}

To achieve this, twenty seven ratios were calculated for a sample of twenty eight industrial firms, half of which had failed, from its financial statement for the fourth year following three years of losses for the purpose of analysis.

These ratios were analyzed using the statistical method known as the logistic regression to reach the best form of financial ratios that can distinguish between industrial distressed and non-distressed firms in the first, second and third year before distress.

These ratios were unloaded at SPSS program in the form of variable numbered 27 variables so that each variable represents a certain financial ratio. Data were analyzed statistically using logistic analysis (Binary regression) as a method which is compatible with these data. One of the first studies to predict the failure of companies using this model, Holson study (1980) and Zavgren study (1985).

Logistics analysis has been used as a method of multivariate analysis to reach a mathematical model, which consists of a set of financial ratios to predict distress of industrial companies, where this method is used for classification or prediction in studies where the dependent variable is descriptive variable takes two values crossing them $(1,0)$, which is known as the binomial nominal variables, the case of distress takes the value of 1 and the case of no distress takes 0 , while independent variables it can be quantitative or nominal variables.

\section{The Result and Recommendation}

The developed model contained three financial ratios which are net working capital to owner's equity, account receivable turnover ratio, and owner's equity to fixed assets ratio, this model is:

$\log \llbracket($ odds $) \rrbracket=23.617+(7.776) x \_7-(10.227) x \_20-(4.802) x \_22$

$\mathrm{X}$ 7: Working capital ratio to equity.

X_20: turnover of accounts receivable.

X_22: the ratio of equity to fixed assets.

Enabling the re-classification of industrial firms in the sample within the two groups of distressed and nondistressed categories with accuracy amounted $89.3 \%$ in the year of analysis, whereas its accuracy in discriminating between the failed and the non-failed firms was $67.9 \%, 78.6 \%, 74.1 \%$ in the first, second, and third years respectively before distress. Moreover, the model's accuracy in classifying another sample of ten firms, half of which had failed, was $90 \%$ in the first year before distress.

The study finished with some useful recommendations. The most important of them is the utilization of the proposed model by the companies control department, Ministry of industry \& Trade, current and prospective investors and company management in order to predict financial failure of industrial companies in Jordan. The study, also, recommended the inclusion of non-financial indicators such as firm size, its age, the various economic variables,... etc, as well as financial indicators such as financial ratios when building mathematical models to predict financial failure.

\section{References}

Zavgren, C., spring (1985), "Assessing the Vulnerability to Failure of American Industrial Firms: A Logistic Analysis", Journal of Business Finance and Accounting, 12(1), pp19-45.

Altman, Edward I., (1968), "Financial Ratios Discriminant Analysis and the Prediction of Corporate Bankruptcy", Journal of Finance, Vol.23, No.4, pp589-609.

Beaver, William, (1966), "Financial Ratios as Prediction of Failure", Journal of Accounting Research, pp71-111.

Ohlson, J., (1980), "Financial Ratios and the Probalistic Prediction of Bankruptcy", Journal of Accounting Research, Vol 18, No 2, spring, pp 109-131.

Rugby,(2006), " Using financial ratios to predict financial failure of Jordanian corporation using discriminatory and logit analysis", Arabic journal of administration,vo13,No 2,pp 149-173.

Islambouli,(2003), " Using financial ratios to predict financial distress of industrial companies General food in Syria ", master thesis, Damascus university, Syria. 
Annex 1

\begin{tabular}{|c|c|c|c|}
\hline Company & Asset size & $\begin{array}{l}\text { The year of the losses for the failed } \\
\text { company and the profits for its similar }\end{array}$ & Observation \\
\hline INOH & $60,975,264$ & $2000,2001,2002$ & Failed company make losses for 3 year successive \\
\hline JODA & $60,184,306$ & $2000,2001,2002$ & Non failed company similar to the previous \\
\hline NATP & $596,494,183$ & $1997,1998,1999$ & Failed company make losses for 3 year successive \\
\hline JOST & $596,273,390$ & $1997,1998,1999$ & Non failed company similar to the previous \\
\hline NAST & $118,941,653$ & $1996,1997,1998$ & Failed company make losses for 3 year successive \\
\hline APHC & $117,808,594$ & $1996,1997,1998$ & Non failed company similar to the previous \\
\hline JSLC & $66,356,292$ & $2000,2001,2002$ & Failed company make losses for 3 year successive \\
\hline UADI & $66,723,486$ & $2000,2001,2002$ & Non failed company similar to the previous \\
\hline APCT & $87,191,259$ & $2002,2003,2004$ & Failed company make losses for 3 year successive \\
\hline JOPI & $88,037,873$ & $2002,2003,2004$ & Non failed company similar to the previous \\
\hline NDAR & $101,858,192$ & $2000,2001,2002$ & Failed company make losses for 3 year successive \\
\hline NATC & $115,382,175$ & $2000,2001,2002$ & Non failed company similar to the previous \\
\hline AMAN & $48,837,475$ & 2000 to 2006 & Failed company make losses for 3 year successive \\
\hline PERL & $47,010,833$ & $2000,2001,2002$ & Non failed company similar to the previous \\
\hline WOOD & $143,624,309$ & $1997,1998,1999$ & Failed company make losses for 3 year successive \\
\hline ENPC & $143,339,797$ & $1997,1998,1999$ & Non failed company similar to the previous \\
\hline TRAV & $42,662,415$ & $2001,2002,2002$ & Failed company make losses for 3 year successive \\
\hline JOIC & $37,367,485$ & $2001,2002,2002$ & Non failed company similar to the previous \\
\hline IENG & $136,327,534$ & 2002 to2007 & Failed company make losses for 3 year successive \\
\hline ASPMM & $147,699,657$ & $2002,2003,2004$ & Non failed company similar to the previous \\
\hline WIRE & $215,040,890$ & $2000,2001,2002,2003$ & Failed company make losses for 3 year successive \\
\hline AlFF & $209,286,639$ & $2000,2001,2002$ & Non failed company similar to the previous \\
\hline AEIN & $122,884,189$ & $1996,1997,1998$ & Failed company make losses for 3 year successive \\
\hline UMIC & $120,191,638$ & $1996,1997,1998$ & Non failed company similar to the previous \\
\hline WOOL & $12,471,925$ & $2000,2001,2002$ & Failed company make losses for 3 year successive \\
\hline GENM & $24,025,670$ & $2000,2001,2002$ & Non failed company similar to the previous \\
\hline ICER & $123,456,446$ & $1996,1997,1998$ & Failed company make losses for 3 year successive \\
\hline JOIR & $124,113,267$ & $1996,1997,1998$ & Non failed company similar to the previous \\
\hline
\end{tabular}

Annex 2

\begin{tabular}{|c|c|c|l|}
\hline Company & Asset size & $\begin{array}{c}\text { The year of the losses for the failed } \\
\text { company and the profits for its similar }\end{array}$ & Observation \\
\hline ICAG & $193,494,568$ & $2004,2005,2006$ & Failed company make losses for 3 year successive \\
\hline GENI & $195,930,596$ & $2004,2005,2006$ & Non failed company similar to the previous \\
\hline INMJ & $14,237,033$ & 2003 to 2008 & Failed company make losses for 3 year successive \\
\hline JOWL & $25,025,873$ & $2003,2004,2005$ & Non failed company similar to the previous \\
\hline JPPC & $125,498,747$ & $2006,2007,2008$ & Failed company make losses for 3 year successive \\
\hline JVOI & $122,636,144$ & $2006,2007,2008$ & Non failed company similar to the previous \\
\hline Jordanian dibarra & $38,615,484$ & $2005,2006,2007$ & Failed company make losses for 3 year successive \\
\hline UNIC & $31,214,127$ & $2005,2006,2007$ & Non failed company similar to the previous \\
\hline JOCF & $125,519,354$ & $2006,2007,2008$ & Failed company make losses for 3 year successive \\
\hline JOPC & $133,106,342$ & $2006,2007,2008$ & Non failed company similar to the previous \\
\hline
\end{tabular}

